НАУКОВИЙ ВІСНИК

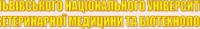

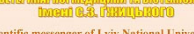

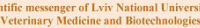

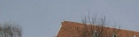
19 W

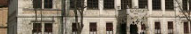
СЕРА: ХАРчОВ технологі Том 22 № 94 2020

\section{Науковий вісник Яьвівського національного університету} ветеринарної медицини та біотехнодогій імені С.3. Гжицького. Серія: Харчові технологіі

\author{
Scientific Messenger of Lviv National University \\ of Veterinary Medicine and Biotechnologies.
}

Series: Food Technologies doi: 10.32718/nvlvet-f9407

https://nvlvet.com.ua/index.php/food

UDC 637.5: 664.2

\title{
Investigation of the effect of amylopectin starch on the properties of meat systems
}

\author{
Yu. P. Kryzhova ${ }^{1}$, M. M. Antoniuk ${ }^{2}$, A. D. Antoniv ${ }^{1}$, M. A. Sydorenko ${ }^{1}$ \\ ${ }^{1}$ National University of Life and Environmental Sciences of Ukraine, Kyiv, Ukraine \\ ${ }^{2}$ Rivne Medical Academy, Department of Chemical-Pharmaceutical Disciplines, Rivne, Ukraine
}

Article info

Received 03.09.2020

Received in revised form 05.10 .2020

Accepted 06.10.2020

National University of Life and Environmental Sciences of Ukraine, Polkovnika Potekhina Str., 16, Kyiv, 03041, Ukraine. Tel.: +38-093-037-00-77 E-mail: yuliya.kryzhova@ukr.net

Rivne Medical Academy, Department of ChemicalPharmaceutical Disciplines, Karnaukhova Str., 53, Rivne, 33000, Ukraine.

Tel: +38-097-435-42-86 E-mail:mariant@ukr.net
Kryzhova, Yu. P., Antoniuk, M. M., Antoniv, A. D., \& Sydorenko, M. A. (2020). Investigation of the effect of amylopectin starch on the properties of meat systems. Scientific Messenger of Lviv National University of Veterinary Medicine and Biotechnologies. Series: Food Technologies, 22(94), 32-36. doi: $10.32718 /$ nvlvet-f9407

Decrease of meat quality results in the use of phosphate supplements, which increase the moisturebinding and emulsifying ability of meat, stabilize the $\mathrm{pH}$ of meat, color formation and oxidative processes in meat products. The most modern technological schemes of meat production involve the use of food phosphates, due to their ability to significantly increase the functional and technological potential of muscle proteins. However, consumption of meat products which contain food phosphates increases the intake of phosphorus in the human body, which has a negative impact on health. Therefore, today the meat processing industry is faced with the question of finding alternatives to phosphate supplements that would have the above mentioned functional properties and be safe for human health. To achieve the desired texture of sausages and structural and mechanical properties of minced meat they use starches. Unlike a regular starch, Perfectabind $C$ amylopectin starch forms highly viscous pastes when heated with water, stable when stored at low and high temperatures, when the pH is lowered or when freezing and thawing. Amylopectin starches have a lower gelatinization temperature, the starch past is transparent, resistant to acidity and mechanical impact, odorless.Their use allows to improve the consistency, taste of food, completely eliminate phosphates, increase technological and economic performance. The properties of native potato starches, modified with Eline VE 510 and amylopectin Perfectabind C have been studied, namely: paste production, viscosity, effect on carrageenan gel strength, organoleptic and functionaltechnological parameters of minced meat and sausages. Studies have shown that amylopectin starch Perfectabind $C$ has a high viscosity, minimal effect on the strength of the carrageenan gel, which is $375 \mathrm{~g} / \mathrm{cm}^{2}$, increases the moisture holding capacity of the product by $11.8 \%$, improves the organoleptic characteristics of sausages and increases their yield by $5 \%$ with complete replacement of food phosphates, which is positive and allows to produce safe meat products.

Key words: amylopectin starch, minced meat, viscosity, phosphates, texture, functionality, gel strength.

\section{Дослідження впливу амілопектинового крохмалю на властивості м'ясних систем}

\author{
Ю. П. Крижова ${ }^{1}$, М. М. Антонюк ${ }^{2}$, А. Д. Антонів ${ }^{1}$, М. А Сидоренко ${ }^{1}$ \\ ${ }^{1}$ Національний університет біоресурсів і природокористування Украӥни, м. Київ, Украӥна \\ ${ }^{2}$ КЗВО “Рівненська медична академія” РОР, м. Рівне, Україна
}

\footnotetext{
Зниження якісних показників м'яса обумовлює застосування фосфатних препаратів, які підвищують вологозв'язуючу і емульгуючу здатність м'яса, стабілізують величину рН м'яса, кольороутворення і окисні процеси в м'ясопродуктах. Більшість сучасних технологічних схем виробництва м'ясопродуктів передбачає використання харчових фосфатів, шео пояснюється їхньою здатністю істотно збільшувати функиіонально-технологічний потенціал м'язових білків. Проте вживання м'ясопродуктів, щзо містять харчові фосфати, призводить до збільшення надходження в організм людини фосфору, шо має негативний вплив на здоров'я. Тому сьогодні перед м'ясопереробною галуззю гостро стоїть питання пошуку альтернативних фосфатам препаратів, які б володіли вищеперерахованими функціональними властивостями і були безпечними для здоров'я людини. Для досягнення необхідної текстури
} 
ковбасних продуктів та структурно-механічних властивостей фариу використовують крохмалі. На відміну від звичайного крохмалю, амілопектиновий крохмаль Perfectabind C при нагріванні з водою утворює високов'язкі клейстери, стійкі при зберіганні в умовах низьких та високих температур, при зниженні рН та при заморожуванні-розморожуванні. Амілопектинові крохмалі мають нижчу температуру клейстеризації, клейстер з них прозорий, стійкий при підвищенні кислотності та механічному впливі, без запаху. Їх застосування дозволяє поліпшити консистенцію, смакові якості харчового продукту, повністю виключити фосфати, підвищити технологічні та економічні показники. Було досліджено властивості крохмалів нативного картопляного, модифікованого Eline VE 510 та амілопектинового Perfectabind C, а саме: отримання клейстерів, стан в'язкості, вплив на силу гелю карагенану, органолептичні та функціонально-технологічні показники фаршу та сосисок. Дослідженнями встановлено, шуо амілопектиновий крохмаль Perfectabind C має високу в'язкість, мінімальний вплив на силу гелю карагенану, яка становить 375 г/см ${ }^{2}$, на 11,8\% підвищує вологоутримуючу здатність продукту, поліпшує органолептичні показники сосисок та на 5 \%, підвищує їх вихід при повній заміні харчових фосфатів, щу є позитивним та дає можливість виробляти безпечні м'ясні продукти.

Ключові слова: амілопектиновий крохмаль, фари, в'язкість, фосфати, текстура, функиіональність, сила гелю.

\section{Вступ}

Використання полісахаридів, а саме крохмалю, забезпечує стабільність м'ясних систем та поліпшує їхні структурно-механічні властивості, а також консистенцію і смак продукту, підвищує вихід готової продукції. Потреба в крохмалепродуктах з різними функціонально-технологічними характеристиками у виробництві м'ясних продуктів постійно зростає. Дослідженнями встановлено, що після термічного оброблення ковбас $з$ використанням крохмалю підвищується вологоутримуюча здатність фаршу. Крохмаль при нагріванні завдяки своїй молекулярній структурі розкладається на декстрини, які здатні утворювати клейстер, підвищуючи жироутримуючу здатність (Behall \& Howe, 1995; Li \& Yeh, 2003; Pietrasik \& Soladoye, 2021).

Завдяки застосуванню крохмалю підвищується в'язкість фаршу і частка сухих речовин в ньому. Враховуючи вплив крохмалю на консистенцію продукту, проведено дослідження щодо застосування функціональних крохмалів (Sarafanova, 2004; Yang \& Park, 1998).

Функціональні крохмалі володіють підвищеними функціонально-технологічними характеристиками i застосовуються для заміни фосфатів, зниження втрат при термічному обробленні. Роль крохмалю полягає в регулюванні бажаних властивостей готового продукту та показників економічної ефективності. Перевагою крохмалепродуктів $\epsilon$ ідеальна їх сполучуваність 3 іншими харчовими інгредієнтами, а саме карагенаном, молочними білками, соєвими білками, плазмою крові, яйцепродуктами тощо. Використання крохмалю, особливо амілопектинового, в симбіозі з білковими інгредієнтами знижує пористість продуктів і підвищує їхню “кусаємість” (Puolanne et al., 2001; Zhushman, 2007).

Амілопектиновий крохмаль Perfectabind C - це воскоподібний картопляний крохмаль, який містить понад 99 \% амілопектину, що надає унікальних функціональних властивостей фаршу та текстури, а також чистий аромат, глянцевий вигляд, відмінне кремове відчуття. Він зручний завдяки нижчій температурі желатинізації та досить високій гарячій в'язкості, що $\epsilon$ великою перевагою при використанні крохмалю в м'ясних продуктах.

Розробники технології отримання амілопектинового крохмалю стверджують, що його використання дає можливість виробництва варених ковбас без ви- користання фосфатів, що й було взято за основу даних досліджень.

Сучасна промисловість широко застосовує солі фосфорної кислоти, що призводить до надлишку їх в організмі людини. Надмірний вміст фосфатів неминуче призводить до зміщення балансу фосфору і кальцію в організмі, який повинен перебувати у співвідношенні 1:1. Щоб відновити співвідношення, організм починає забирати відсутній кальцій 3 найближчих джерел, зокрема 3 кісток і зубів. Все це викликає ослаблення кісткової тканини і розвиток серйозних захворювань Ще одним симптомом дизбалансу кальцію і фосфору стає порушення сну.

Актуальність теми. Пошук альтернативних фосфатам компонентів підтверджується безліччю досліджень в даній області, а використання амілопектинового крохмалю в технології м'ясних продуктів не впроваджено. Актуальністю теми $є$ використання амілопектинового крохмалю, що дасть змогу замінити солі фосфорних кислот, здешевити виробництво, спростити технологічний процес, зменшити втрати, підвищити якість готового продукту. Більш глибоке та комплексне дослідження амілопектинового крохмалю внесе вагомий вклад у розвиток м'ясної промисловості та харчових технологій.

Мета роботи - наукове обгрунтування ефективності використання нативного амілопектинового крохмалю Perfectabind C у виробництві сосисок; завдання - визначення оптимальної кількості внесення амілопектинового крохмалю; проведення комплексних досліджень фаршу та готової продукції.

\section{Матеріал і методи досліджень}

Для визначення властивостей нативного амілопектинового крохмалю, органолептичних, фізико-хімічних, функціонально-технологічних та структурно-механічних показників фаршу та готових сосисок застосовували стандартні методи досліджень. Вміст вологи визначали арбітражним методом, вологозв'язуючу здатність методом пресування, $\mathrm{pH}$ - за допомогою $\mathrm{pH}$-метра, пенетрацію - на пенетрометрі Ulab 3 - 31 M, властивості крохмалів - заварюванням крохмалів у різних розчинах та за різної температури, вплив крохмалів на силу гелю карагенану - за допомогою приладу Валента нагріванням водного 1 \%-го розчину каппа карагенану, 2 \%-го розчину $\mathrm{NaCl}$, 0,2 \%-го розчину $\mathrm{KCl} з$ додаванням різних видів крохмалів 3 подальшим охолодженням та витримуванням протягом 5 годин за температури $15^{\circ} \mathrm{C}$. 


\section{Результати та їх обговорення}

Були проведені дослідження властивостей крохмалю Perfectabind $\mathrm{C}$ порівняно зі звичайним нативним картопляним крохмалем та модифікованим картопляним крохмалем Eliane VE 510, а саме: вимірювання температури заварювання крохмалю (5\% водний розчин, 3 \% солі) та порівняння структури і в'язкості отриманих розчинів після 30 хв заварювання за температури $90 \pm 2{ }^{\circ} \mathrm{C}$.

Результати досліджень показано в таблиці 1.

Таблиця 1

Результати експериментальних досліджень крохмалю

\begin{tabular}{|c|c|c|c|}
\hline Найменування крохмалю & $\begin{array}{c}\text { Температура } \\
\text { заварювання, }{ }^{\circ} \mathrm{C}\end{array}$ & $\begin{array}{c}\text { Текстура крохмального } \\
\text { клейстеру }\end{array}$ & $\begin{array}{c}\text { В’язкість (по Брабендеру) } \\
\text { після } 30 \text { хв клейстеризації за } \\
\text { температури } 90 \pm 2 \text { C, BU }\end{array}$ \\
\hline Нативний картопляний крохмаль & 63,5 & Злегка тягнеться, слабкий гель & 1200 \\
\hline Eliane VE 510 & 65 & Слабкий гель & 1300 \\
\hline Perfectabind $\mathrm{C}$ & 61 & Стабільний гель & 1600 \\
\hline
\end{tabular}

За результатами досліджень можна констатувати, що за текстурою отриманих клейстерів відслідковується вміст амілозної фракції у крохмалі. Відомо, що желе утворюється при лінійній будові ланцюга крохмальних зерен. Тягнуча текстура вказує на те, що зерна крохмалю почали руйнуватися i вивільняти зв'язану раніше вологу. У ковбасних виробах це може спричинити бульйонно-жирові набряки.

В'язкість нативного картопляного крохмалю найнижча серед досліджуваних. А найвищу в'язкість має амілопектиновий крохмаль Perfectabind $\mathrm{C}$, адже амілопектинова фракція має вищу вологозв'язуючу здатність та зерна крохмалю після нагрівання залишаються цілими.

Дуже важливим фактором для використання у ковбасному виробництві є показник, як крохмаль впли- ває на силу гелю карагенану. Адже всім добре відомо, що у м'ясній промисловості широко застосовується карагенан для збільшення виходу та текстурування продукту. Для перевірки впливу крохмалю на силу карагенану був проведений такий експеримент. Всі зразки водного розчину містили по $1 \%$ напівочищеного каппа карагенану, 2 \% NaCI та 0,2 \% KCI. У другий, третій та четвертий зразок було додано по $1 \%$ нативного картопляного крохмалю, амілопектинового картопляного Perfectabind C та модифікованого картопляного Eliane VE510 відповідно. Зразки нагрівали до $80{ }^{\circ} \mathrm{C}$ і витримували протягом 30 хв. Охолоджували і витримували за температури $15^{\circ} \mathrm{C}$ протягом 5 год. Після того вимірювалась сила гелю за допомогою приладу Валента. Дані експерименту наведені в таблиці 2.

Таблиця 2

Вплив крохмалів на силу гелю карагенану

\begin{tabular}{cccccccc}
\hline № & $\begin{array}{c}\text { Напівочищений каппа } \\
\text { карагенан }\end{array}$ & KCI & NaCI & Perfectabind C & $\begin{array}{c}\text { Eliane VE } \\
510\end{array}$ & $\begin{array}{c}\text { Нативний } \\
\text { крохмаль }\end{array}$ & $\begin{array}{c}\text { Сила гелю, } \\
\text { г/см }{ }^{2}\end{array}$ \\
\hline 1 & $1 \%$ & $0,2 \%$ & $2 \%$ & - & - & - & 457 \\
2 & $1 \%$ & $0,2 \%$ & $2 \%$ & - & - & $1 \%$ & 359 \\
3 & $1 \%$ & $0,2 \%$ & $2 \%$ & $1 \%$ & - & - & 375 \\
4 & $1 \%$ & $0,2 \%$ & $2 \%$ & - & $1 \%$ & - & 319 \\
\hline
\end{tabular}

Дані дослідження показали, що на силу карагенану найбільший вплив має модифікований крохмаль Eliane VE 510, тому він найменше підходить для використання разом з карагенаном. А амілопектиновий крохмаль Perfectabind $\mathrm{C}$ мав найменший вплив на силу гелю, отже його можливо використовувати паралельно $з$ карагенаном для виробництва ковбасних виробів.

Підсумовуючи отримані результати, можна стверджувати, що амілопектиновий крохмаль Perfectabind С за своїми характеристиками перевершує нативний та модифікований картопляний крохмаль за рахунок нижчої температури початку клейстеризації, високого водозв'язування і зменшеного негативного впливу на силу карагенану.

В ході проведеної роботи були розроблені дві дослідні рецептури сосисок: одна - 3 використанням фосфатів та амілопектинового крохмалю Perfectabind $\mathrm{C}$, друга - 3 використанням амілопектинового крохмалю Perfectabind С. В рецептурі № 1 використовува- ли $0,15 \%$ фосфатів та $0,15 \%$ амілопектинового крохмалю Perfectabind C; в рецептурі № $2-0,3 \%$ досліджуваного крохмалю та без використання фосфатів. Аналогом слугували сосиски "Молодіжні" 1 с, які були взяті за контроль.

Варіанти рецептур наведені в таблиці 3.

Недоліком контрольної рецептури є вміст фосфатів. Не можна не відзначити, що харчові фосфати є джерелом фосфору, необхідного для нормального функціонування опорно-рухової системи, нервової системи, обміну речовин тощо. Однак допустиме добове споживання для більшості харчових фосфатів складає 70 мг/кг маси тіла людини в день.

Застосування харчових фосфатів при виробництві м'ясних продуктів ускладнюється тим, що м'ясна сировина містить достатню кількість природного фосфату (до $0,5 \%$ в перерахунку на $\mathrm{P}_{2} \mathrm{O}_{5}$ ). Таким чином, додаткове внесення фосфатів призводить до значної переваги співвідношення кальцію і фосфору в 
бік останнього. Беручи до уваги, що надлишковий фосфор здатний вимивати кальцій з організму і тим самим призводити до розвитку остеопорозу, важливим завданням є звести до мінімуму вміст фосфору в м'ясних продуктах.

Таблиця 3

Рецептури сосисок, кг на 100 кг сировини

\begin{tabular}{lccc}
\hline \multirow{2}{*}{ Сировина } & \multicolumn{3}{c}{ Рецептури } \\
\cline { 2 - 4 } & Контроль & № 1 & № 2 \\
\hline Яловичина знежилована 1 сорт & 45 & 45 & 45 \\
Свинина знежилована жирна & 55 & 55 & 55 \\
Всього & 100 & 100 & 100 \\
\multicolumn{1}{c}{ Прянощі та матеріали, г на 100 кг сировини } \\
Сіль & 2200 & 2200 & 2200 \\
Цукор-пісок & 120 & 120 & 120 \\
Перець духмяний мелений & 80 & 80 & 120 \\
Горіх мускатний мелений & 40 & 40 & 40 \\
Перець чорний мелений & 120 & 120 & 120 \\
Суміш фосфатів ТF-318 & 300 & 150 & - \\
Рerfectabind С & - & 150 & 300 \\
\hline
\end{tabular}

Аналізуючи роботи у сфері вивчення впливу фосфатів на стан судин і органів тіла, з цим складно не погодитися. Якщо раніше вважали, що єдиний ризик для здоров'я, пов'язаний 3 надмірним споживанням фосфатів, полягає в кальцинозі судин, то в даний час стало відомо, що фосфати викликають порушення в серцево-судинній системі.

Проте ряд дослідників вважають, що цитрати здатні замінити фосфати, особливо при використанні замороженого м'яса, у зв'язку з тим, що в результаті процесів заморожування-розморожування актоміозиновий комплекс в м'язовій тканині розпадається на актин і міозин, при цьому роль фосфатів зводиться тільки до підвищення $\mathrm{pH}$. Противники харчових добавок, ймовірно, зауважать, що цитрати, як і фосфати, $\epsilon$ харчовими добавками і мають індекс $\mathrm{E}$, тому така заміна нічого не дає, але це не так. Безперечно, харчові цитрати є харчовими добавками, однак на відміну від фосфатів, вони не мають негативного впливу на баланс кальцію в організмі, крім того, можуть бути джерелом калію або кальцію в продукті (в разі застосування цитрату калію і цитрату кальцію). Результати досліджень впливу різних видів фосфатів і цитрату натрію на технологічні характеристики м'яса показали, що використання цитрату натрію не дозволяє досягти настільки ж ефективного впливу на м'ясну сировину, як фосфатовмісні препарати (Sarafanova, 2004).

Кількість утриманої вологи характеризується вологоутримуючою здатністю, що є різницею між вмістом вологи у фарші та кількістю вологи, яка відділилася у процесі термічного оброблення. Показники вологоутримуючої здатності особливо важливі для виробництва сосисок, тому що саме від цього показника залежить соковитість готових виробів. Динаміка зміни вологоутримуючої здатності готових сосисок зображена на рисунку 1.

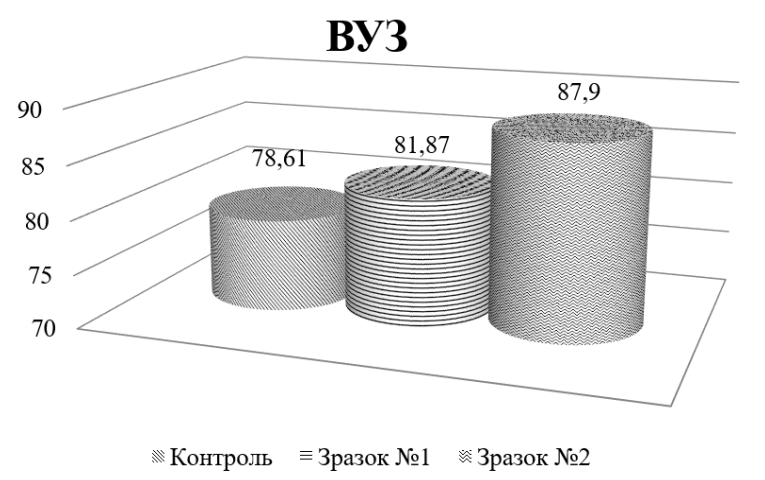

Рис. 1. Вологоутримуюча здатність сосисок, $\%$

За результатами проведених досліджень можна відмітити, що в дослідного зразка № 2, до рецептури якого входить лише амілопектиновий крохмаль, вологоутримуюча здатність підвищилась на 11,8 \% порівняно 3 контрольним зразком. Тобто, можна стверджувати, що застосування амілопектинового крохмалю дає можливість збільшити кількість зв'язаної та утриманої вологи фаршем без застосування фосфатовмісних препаратів.

Також встановлено, що застосування амілопектинового крохмалю Perfectabind C замість фосфатів підвищує вихід готового продукту на 5 \%, що є важливим технологічним показником.

\section{Висновки}

Встановлена можливість застосування амілопектинового крохмалю Perfectabind $\mathrm{C}$ замість фосфатів у виробництві сосисок.

Доведено, що амілопектиновий крохмаль Perfectabind C за своїми властивостями перевершує звичайний нативний картопляний крохмаль та певні види модифікованих за рахунок низької температури клейстеризації, високої водозв'язуючої здатності та добрих показників при комбінації з карагенаном.

Проведено органолептичну оцінку розроблених сосисок, яка підтвердила доцільність застосування амілопектинового крохмалю Perfectabind C 3 метою надання готовому продукту більшої соковитості та ніжності внаслідок збільшення вологоутримуючої здатності.

Досліджено та підтверджено позитивний вплив амілопектинового крохмалю Perfectabind $\mathrm{C}$ на фізикохімічні, функціонально-технологічні та структурномеханічні показники сосисок; вихід сосисок підвищився на $5 \%$.

Отримані результати проведеної роботи свідчать про те, що використання амілопектинового крохмалю Perfectabind $\mathrm{C}$ дає можливість повністю відмовитись від фосфатів у технології виробництва сосисок та виготовляти продукти зі збільшеним виходом та кращими органолептичними властивостями.

Перспективи подальших досліджень. Дані дослідження мають перспективу у виробництві всієї групи варених ковбасних продуктів. 


\section{References}

Behall, K. M., \& Howe, J. C. (1995). Effect of long-term consumption of amylose vs amylopectin starch on metabolic variables in human subjects. The American Journal of Clinical Nutrition, 61(2), 334-340. doi: 10.1093/ajen/61.2.334.

DSTU 4436:2005 (2005). Kovbasy vareni, sosyski, sardelki, khliby miasni. Chynnyi vid 2005-07-05. K.:Ukr NDNTS (Natsionalni standarty Ukrainy). URL: https://dnaop.com/html/33977_3.html (in Ukrainian).

Hamm, R. (1970). Interaction between phosphates and meat proteins. In Symposium: Phosphates in Food Processing, Demap L.M., Melnychyn P. (editors), AVI Publishing Co., Westport.

Li, J. Y., \& Yeh, A. I. (2003). Effects of starch properties on rheological characteristics of starch/meat complexes. Journal of Food Engineering, 57(3), 287-294. doi: 10.1016/S0260-8774(02)00309-6.
Pietrasik, Z., \& Soladoye, O. P. (2021). Use of native pea starches as an alternative to modified corn starch in low-fat bologna. Meat Science, 171, 108283. doi: 10.1016/j.meatsci.2020.108283.

Puolanne, E. J., Ruusunen, M. H., \& Vainionpaa, J. I. (2001). Combined effects of $\mathrm{NaCl}$ and raw meat $\mathrm{pH}$ on water-holding in cooked sausage with and without added phosphate. Meat Science, 58(1), 1-7. doi: 10.1016/S0309-1740(00)00123-6.

Sarafanova, L. A. (2004). Pishhevye dobavki: Jenciklopedija. SPb: GIORD (in Russian).

Yang, H., \& Park, J. W. (1998). Effects of Starch Properties and Thermal-processing Conditions on SurimiStarch Gels. LWT - Food Science and Technology, 31(4), 344-353. doi: 10.1006/fstl.1997.0366.

Zhushman, A. I. (2007). Modificirovannye krahmaly. M.: Pishhepromizdat (in Russian). 